\title{
Spikelet sterility in rice genotypes affected by temperature at microsporogenesis
}

\author{
Natalia M. de Souza ${ }^{1}$, Rubens Marschalek ${ }^{2}$, Luis Sangoi ${ }^{1} \&$ Francieli S. Weber $^{1}$ \\ ${ }^{1}$ Universidade do Estado de Santa Catarina/Centro de Ciências Agroveterinárias. Lages, SC. E-mail: naty_natynatalia@hotmail.com (Corresponding author); \\ luis.sangoi@udesc.br; francieliweber@yahoo.com.br \\ ${ }^{2}$ Empresa de Pesquisa Agropecuária e Extensão Rural de Santa Catarina/Estação Experimental de Itajaí. Itajaí, SC. E-mail: rubensm@epagri.sc.gov.br
}

\section{Key words:}

Oryza sativa

booting

cold

controlled environment

\begin{abstract}
A B S T R A C T
This study evaluated the effect of temperatures during the phase of microsporogenesis on spikelet sterility of paddy rice and identified genotypes tolerant to low temperatures at this growth stage. The inbreds SC681, SC491, and SC676 and the cultivars Epagri 109 and SCS116 Satoru were assessed. The genotypes were submitted for three days in a growth chamber to five temperatures at microsporogenesis: $9,12,15,18$, and $21^{\circ} \mathrm{C}$. For each tested temperature, a control was kept in the greenhouse under environmental conditions. After harvest, full and empty spikelets were counted and weighed and the percentage of spikelet sterility was determined. Data were evaluated by variance analysis using the F test. Averages were compared by Tukey's test and regression analysis. The highest spikelet sterilities were observed when the genotypes were exposed to the temperatures of 9 and $12{ }^{\circ} \mathrm{C}$. Genotype spikelet sterility was similar to that of the control at $21^{\circ} \mathrm{C}$. The inbred SC 676 presented higher tolerance to lower temperatures is therefore potentially suited to generate a cultivar with adequate agronomic performance in rice growing areas prone to cold conditions at microsporogenesis.
\end{abstract}

\section{Palavras-chave: \\ Oryza sativa \\ emborrachamento \\ frio}

ambiente controlado

\section{Esterilidade de espiguetas em genótipos de arroz irrigado afetada pela temperatura na microsporogênese}

\section{R E S U M O}

Este trabalho teve como objetivo avaliar o efeito da temperatura na fase de microsporogênese sobre a esterilidade de espiguetas de arroz irrigado identificando, nesta fase, genótipos tolerantes a baixas temperaturas. Foram testadas as linhagens SC681, SC491 e SC676 e as cultivares Epagri 109 e SCS116 Satoru. Os genótipos foram submetidos por três dias em câmara de crescimento a cinco temperaturas na microsporogênese: $9,12,15,18$ e $21^{\circ} \mathrm{C}$. Para cada temperatura um tratamento testemunha foi mantido a temperatura ambiente na casa de vegetação. Após colheita realizaram-se a contagem e a pesagem das espiguetas cheias e vazias, determinando-se a percentagem de esterilidade. Os dados foram submetidos à análise de variância pelo teste F. Quando significativas, as médias foram comparadas pelo teste de Tukey e análise de regressão. A maior esterilidade foi observada nos genótipos submetidos às temperaturas de 9 e $12^{\circ} \mathrm{C}$. A esterilidade foi similar entre testemunhas e a $21^{\circ} \mathrm{C}$. A linhagem SC676 apresentou maior tolerância à ocorrência de baixas temperaturas mostrando-se promissora para gerar uma cultivar com desempenho agronômico adequado, em regiões orizícolas propensas à ocorrência de frio na microsporogênese. 


\section{INTRODUCTION}

Paddy rice is grown in several regions, climatic conditions, and production systems around the world (Artacho et al., 2011). However, low temperatures during critical growth stages affect its productivity (Shimono et al., 2007; SOSBAI, 2014). The extension of damage caused by cold incidence depends on several factors, such as the duration and intensity of thermic stress, crop management, cultivar, and plant development stage (Cruz \& Milach, 2000).

The growth stage R2 (microsporogenesis) of the scale proposed by Counce et al. (2000) is the phase most sensitive to low temperatures (Rozzetto et al., 2013). At this stage, temperatures below $17^{\circ} \mathrm{C}$ negatively impact pollen grain formation (SOSBAI, 2014), resulting in increased spikelet sterility in this period (Baruah et al., 2009).

In the South of Brazil, where the two larger paddy rice producer states are located, Rio Grande do Sul and Santa Catarina, low temperatures are one of the major factors reducing crop grain yields (Cruz et al., 2006). Rice is a spring/ summer cereal that can be injured by cold throughout the entire growth cycle, from germination to grain maturity, resulting in reduced productivity (Shimono et al., 2007). Cold tolerance during the reproductive period is important to assure high yields in environments where low temperatures are common (Cruz et al., 2010).

In this context, this work evaluated the effect of temperature at microsporogenesis on spikelet sterility of paddy rice, with the aim to identify genotypes tolerant to low temperatures at this growth stage.

\section{Material AND Methods}

The study was carried out at the experimental station of Epagri, located in Itajaí, SC, during the growing season of 2013/2014. The experiment was set up in recipients filled with Dystric Gleysol. Each recipients corresponded to one experimental unit. The recipients were placed in a greenhouse and a growth chamber. The soil chemical attributes were assessed according to the methodology described by Tedesco et al. (1995), obtaining the following values: $\mathrm{pH}-\mathrm{H}_{2} \mathrm{O}=5.1 ; \mathrm{P}=$ $11.9 \mathrm{mg} \mathrm{kg}^{-1} ; \mathrm{K}=64 \mathrm{mg} \mathrm{kg}^{-1} ; \mathrm{MO}=1.7 \% ; \mathrm{Al}=2.9 \mathrm{cmol}_{\mathrm{c}} \mathrm{dm}^{-3}$; $\mathrm{Ca}=0.3 \mathrm{cmol}_{\mathrm{c}} \mathrm{dm}^{-3}, \mathrm{Mg}=0.4 \mathrm{cmol}_{\mathrm{c}} \mathrm{dm}^{-3}$, and clay content $=230$ $\mathrm{g} \mathrm{dm}^{-3}$. The experimental design was completely randomized, with treatments disposed in a multifactorial arrangement $(5 \mathrm{x}$ $5 \times 2$ ) with three replicates. The first factor corresponded to five late ripening genotypes: three inbred lines (SC681, SC491, and SC676) and two commercial cultivars (Epagri 109 and SCS116 Satoru). The inbred lines were selected based on their promising behavior when submitted to low temperatures in experiments carried out by Marschalek et al. (2013) in the High Valley of Itajaí, an important rice production region in the state of Santa Catarina. The selected cultivars are extensively cultivated in Santa Catarina and sensitive to cold weather, previously shown by SCS116 Satoru. During microsporogenesis, each genotype was placed in a growth chamber and submitted to five temperatures: $9,12,15,18$, and $21^{\circ} \mathrm{C}$, corresponding to the second factor. For each evaluated temperature and genotype, a control was kept in the greenhouse under environmental temperatures, corresponding to the third factor. This procedure was needed because the growth chamber only had the capacity to accommodate one thermic treatment per time. Therefore, the five temperature regimes had to be split and the experiment was composed of 150 experimental units ( $5 \times 5 \times 2 \times 3)$.

The experimental units had the following dimensions: $22 \mathrm{~cm}$ of diameter, $20 \mathrm{~cm}$ of height, and the capacity to store $7 \mathrm{~kg}$ of soil. In each recipients, 10 to 15 seeds were sown. After seedling emergence, when plants were at the V2 growth stage, the first thinning was performed, leaving four plants per bucket. At the V6 growth stage, a second thinning was carried out, assuring a final population of two plants in each experimental unit.

All treatments received the same fertilization rates and products, according to the recommendations of SOSBAI (2014) and the results of the soil analysis. The following fertilizer quantities were applied per recipients: $2 \mathrm{~g}$ of triple superphosphate, corresponding to $\mathrm{P}_{2} \mathrm{O}_{5}$ fertilization, and $20 \mathrm{~mL}$ of a $\mathrm{N}+\mathrm{K}_{2} \mathrm{O}$ solution on each top-dressing fertilization. This solution was obtained through the addition and agitation of urea (200 g) and potassium chloride (160 g), diluted in $2 \mathrm{~L}$ of water. Application rates were equivalent to fertilization with $200 \mathrm{mg} \mathrm{kg}^{-1} \mathrm{~N}, 120 \mathrm{mg} \mathrm{kg}^{-1} \mathrm{P}_{2} \mathrm{O}_{5}$, and $70 \mathrm{mg} \mathrm{kg}^{-1} \mathrm{~K}_{2} \mathrm{O}$.

The recipients remained in the greenhouse from sowing (stage S0) to microsporogenesis (stage R2). Six tillers were tagged when they reached R2; this growth stage was identified following the plant development on each experimental unit daily. The tiller stems were periodically opened until the booting stage (R2) was observed.

According to Zaffari et al. (2014), rice microsporogenesis can be identified based on the distance between the flag leaf ligule and the penultimate leaf ligule. This distance must be comprised between $3 \mathrm{~cm}$ (flag leaf ligule $3 \mathrm{~cm}$ below penultimate leaf ligule) and $10 \mathrm{~cm}$ (flag leaf ligule $10 \mathrm{~cm}$ above penultimate leaf ligule). Since plant tillers do not reach the booting stage at the same time, tillers were marked when the distance between the last two leaf ligules ranged from 1 to $2 \mathrm{~cm}$.

After tillers were tagged, the recipients were transferred to the growth chamber so that each thermic regime could be applied. Plants were submitted for three consecutive days to one of the five temperatures previously determined by the trial protocol while the control plants remained in the greenhouse. During this period, light and air relative humidity $(\mathrm{RH})$ in the growth chamber were monitored and kept at $12 \mathrm{~h}$ of light, $12 \mathrm{~h}$ of dark, and $65 \%$ of $\mathrm{RH}$. After three days, the recipients were returned to the greenhouse and kept until harvest.

At the end of the crop cycle, tagged panicles were individually harvested. The remaining panicles from each recipients were harvested in bulk. Each genotype was manually shelled. Empty and full spikelets were separated with a fan and counted. Full and empty spikelet weight and sterility percentage of individual and bulk panicles were determined.

The data were submitted to a variance analysis using the $\mathrm{F}$ test at the significance level of 0.05 probability. When the $\mathrm{F}$ values were significant, the means were compared by Tukey Test. In cases where the temperature effect was significant, a polynomial regression analysis was also performed. Both mean comparisons were carried out at the significance level of 0.05 
probability. The data were analyzed with the Assistat program (Silva \& Azevedo, 2016).

\section{Results AND Discussion}

Variance analysis for the variable "bulk spikelet sterility" detected as significant the triple interaction among genotype $\mathrm{x}$ temperature $\mathrm{x}$ thermic stress/control, indicating that each genotype responded differently to the temperature variation and the imposition of the thermic stress (Table 1).

All genotypes presented a similar percentage of bulk sterility in the control (without application of thermic stress) and when submitted to $21^{\circ} \mathrm{C}$ at microsporogenesis (Table 2). This indicates that the temperature of $21^{\circ} \mathrm{C}$ did not interfere negatively with grain pollen formation. Therefore, the genotypes presented the same behavior compared to the treatment without thermic stress. The rate of genotype spikelet sterility ranged from 25.8 to $36.6 \%$ at the temperature of $21^{\circ} \mathrm{C}$ and in the control. These results differed from those gathered by Rozzetto et al. (2013), who observed lower percentages of spikelet sterility in the control, varying between 7.8 and 19.7\%, in an experiment carried out under the same conditions.

The temperature of $9{ }^{\circ} \mathrm{C}$ had the greatest impact on microsporogenesis of the evaluated genotypes, causing sterility levels of $100 \%$ on Epagri 109, SC491, and SC681, 43.3\% on SC676, and $33.5 \%$ on SCS116 Satoru (Table 2). The lowest percentage of spikelet sterility expressed by cultivar SCS116 Satoru at $9{ }^{\circ} \mathrm{C}$ did not agree with the findings of previous studies because this cultivar was included in the trial due to its cold sensitivity, reported in experiments carried out by Marschalek et al. (2013) in the High Valley of Itajai. The inbred SC676 presented the lowest numeric value of spikelet sterility at the temperature of $18^{\circ} \mathrm{C}$. The genotype's percentage of bulk spikelet sterility did not differ significantly between the temperatures 15 and $21^{\circ} \mathrm{C}$.

Regression analysis of the interaction between temperature and bulk spikelet sterility showed a quadratic behavior of the evaluated genotypes, with the exception of cultivar SCS116 Satoru, for which the regression was not significant (Figure

Table 1. Variance analysis for the variables bulk and individual panicle spikelet sterility of paddy rice

\begin{tabular}{|c|c|c|c|c|}
\hline Source of variation & D.F. & S.Q. & M.S. & $\mathbf{F}$ \\
\hline \multicolumn{5}{|c|}{ Bulks } \\
\hline Genotype & 4 & $1,524.86$ & 381.21 & $4.55^{\star}$ \\
\hline Temperature & 4 & $7,458.03$ & $1,864.51$ & $22.24^{*}$ \\
\hline Thermic Stress/Control & 1 & $1,1867.30$ & $11,867.30$ & $141.58^{*}$ \\
\hline Genotype x Temperature & 16 & $5,937.35$ & 371.08 & $4.43^{\star}$ \\
\hline Genotype $\mathrm{x}$ Thermic stress/Control & 4 & $4,031.55$ & $1,007.89$ & $12.02^{*}$ \\
\hline Temperature $\mathrm{x}$ Thermic stress/Control & 4 & $17,391.70$ & $4,347.92$ & $51.87^{\star}$ \\
\hline Genotype x Temp x Thermic stress/Control & 16 & $6,666.94$ & 416.68 & 4.97 * \\
\hline Treatments & 49 & $54,877.70$ & $1,119.95$ & $13.36^{\star}$ \\
\hline Residue & 100 & $8,381.71$ & 83.82 & \\
\hline Total & 149 & $63,259.40$ & & \\
\hline \multicolumn{5}{|c|}{ Individual Panicles } \\
\hline Genotype & 4 & $1,304.70$ & 326.17 & $2.14^{\mathrm{NS}}$ \\
\hline Temperature & 4 & $16,770.00$ & $4,192.51$ & $27,46^{*}$ \\
\hline Thermic Stress/Control & 1 & $25,545.40$ & $25,545.40$ & $167.34^{*}$ \\
\hline Genotype x Temperature & 16 & $1,719.24$ & 107.45 & $0.70^{\mathrm{NS}}$ \\
\hline Genotype x Thermic stress/Control & 4 & $3,772.59$ & 943.15 & $6.18^{*}$ \\
\hline Temperature x Thermic stress/Control & 4 & $33,887.90$ & $8,471.98$ & $55.50 *$ \\
\hline Genotype x Temp x Thermic stress/Control & 16 & $2,403.09$ & 150.19 & $0.98^{\mathrm{NS}}$ \\
\hline Treatment & 49 & $8,5403.00$ & $1,742.92$ & $11.42^{*}$ \\
\hline Residue & 100 & $15,265.20$ & 152.65 & \\
\hline Total & 149 & $100,668.00$ & & \\
\hline
\end{tabular}

${ }^{*}$ Significant at the probability level of 0.05 ; NS - Not significant at the probability level of 0.05
Table 2. Percentage of bulk spikelet sterility in five paddy rice genotypes submitted to five temperatures at microsporogenesis, in comparison to the control

\begin{tabular}{|c|c|c|c|c|c|}
\hline $\begin{array}{l}\text { Thermic } \\
\text { regime }\end{array}$ & Epagri 109 & SC491 & SC676 & SC681 & $\begin{array}{c}\text { SCS } 116 \\
\text { Satoru }\end{array}$ \\
\hline \multicolumn{6}{|c|}{ Bulk spikelet sterility (\%) } \\
\hline $9^{\circ} \mathrm{C}$ & $100.0 \mathrm{aA}^{*}$ & $100.0 \mathrm{aA}$ & $43.3 \mathrm{bA}$ & $100.0 \mathrm{aA}$ & $33.5 \mathrm{bABC}$ \\
\hline Control & $13.2 \mathrm{aC}$ & $18.3 \mathrm{aCD}$ & $24.6 \mathrm{aAB}$ & $18.7 \mathrm{aCD}$ & $14.3 \mathrm{aC}$ \\
\hline $12^{\circ} \mathrm{C}$ & $22.1 \mathrm{bBC}$ & $47.9 \mathrm{aB}$ & $38.5 \mathrm{abAB}$ & $35.8 \mathrm{abBCD}$ & $39.5 \mathrm{abAB}$ \\
\hline Control & $18.0 \mathrm{aBC}$ & $14.3 \mathrm{aD}$ & $17.2 \mathrm{aB}$ & $16.5 \mathrm{aD}$ & $13.8 \mathrm{aC}$ \\
\hline $15^{\circ} \mathrm{C}$ & $31.0 \mathrm{aBC}$ & $39.5 \mathrm{aBC}$ & $27.0 \mathrm{aAB}$ & $40.8 \mathrm{aBC}$ & $47.5 \mathrm{aA}$ \\
\hline Control & $30.6 \mathrm{aBC}$ & $19.9 \mathrm{aCD}$ & $31.2 \mathrm{aAB}$ & $22.7 \mathrm{aBCD}$ & $20.6 \mathrm{aBC}$ \\
\hline $18^{\circ} \mathrm{C}$ & $29.4 \mathrm{abBC}$ & $41.3 \mathrm{aBC}$ & $19.6 \mathrm{bAB}$ & $45.1 \mathrm{aB}$ & $33.7 \mathrm{abABC}$ \\
\hline Control & $39.6 \mathrm{aB}$ & $36.0 \mathrm{aBCD}$ & $41.3 \mathrm{aAB}$ & $31.1 \mathrm{aBCD}$ & $35.3 \mathrm{aABC}$ \\
\hline $21^{\circ} \mathrm{C}$ & $28.2 \mathrm{aBC}$ & $34.2 \mathrm{aBCD}$ & $25.8 \mathrm{aAB}$ & 29.6 aBCD & $31.9 \mathrm{aABC}$ \\
\hline Control & $27.4 \mathrm{aBC}$ & $29.0 \mathrm{aBCD}$ & $36.6 \mathrm{aAB}$ & $22.3 \mathrm{aBCD}$ & $28.0 \mathrm{aA}$ \\
\hline \multicolumn{6}{|c|}{ CV $\%=27.15$} \\
\hline
\end{tabular}

*Means followed by the same lowercase letter in the row and uppercase letter in the colum are not significantly different by Tukey Test at the significance level of 0.05 probability

1). According to the equations adjusted to the data, the smallest values for this variable were located between 17 and $18{ }^{\circ} \mathrm{C}$, corroborating the observations made by Walter et al. (2010), Nanculao et al. (2013) and Oort et al. (2014), and that temperatures below these values increase rice spikelet sterility. The inbred SC676 presented the smallest rate of increment in bulk spikelet sterility when temperatures dropped from 21 to $9{ }^{\circ} \mathrm{C}$.

The sterility of panicles harvested separately was affected by the double interactions between genotype $\mathrm{x}$ thermic stress/control and temperature $\mathrm{x}$ thermic stress/control, indicating that in the presence of thermic stress, genotypes and temperature responded differently from the controls.

Considering the tagged panicles, the five genotypes had similar percentages of spikelet sterility on the controls that were not subjected to thermic stress (Table 3). Conversely, in the

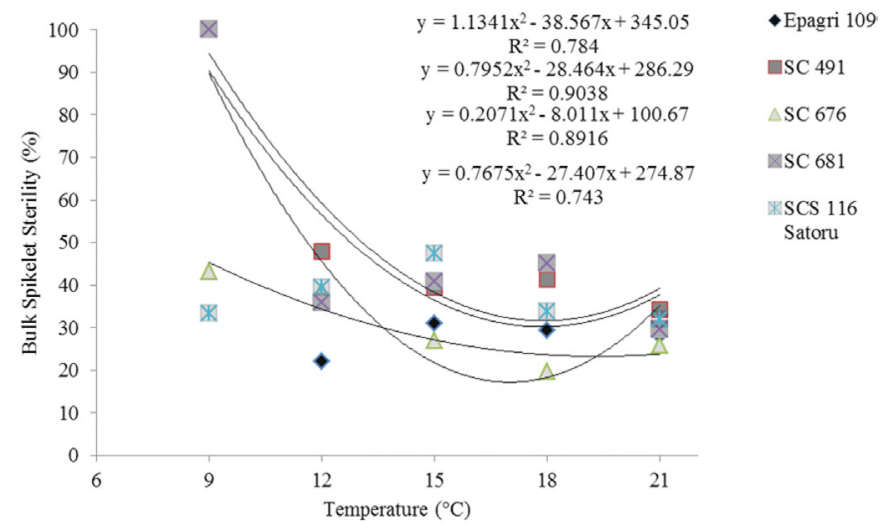

Figure 1. Effect of temperature on the percentage of bulk spikelet sterility of five paddy rice genotypes

Table 3. Overall percentage of tagged panicle spikelet sterility of five paddy rice genotypes in comparison to the control averaged across all five temperatures

\begin{tabular}{lccccc}
\hline $\begin{array}{c}\text { Thermic } \\
\text { regime }\end{array}$ & Epagri 109 & SC491 & SC676 & SC681 & SCS116 Satoru \\
\multicolumn{5}{c}{ Tagged panicle spikelet sterility (\%) } \\
Temperatures $1 /$ & $43.0 \mathrm{bcA}^{*}$ & $59.5 \mathrm{aA}$ & $39.7 \mathrm{aA}$ & $54.9 \mathrm{abA}$ & $55.3 \mathrm{abA}$ \\
Control & $24.1 \mathrm{aB}$ & $23.7 \mathrm{aB}$ & $29.8 \mathrm{aB}$ & $21.0 \mathrm{Ab}$ & $23.2 \mathrm{aB}$ \\
\multicolumn{5}{c}{ CV\% $=33.02$} \\
\hline
\end{tabular}

* Means followed by the same lowercase letter in the row and uppercase letter in the column are not significantly different by Tukey Test at the significance level of 0.05 probability ${ }^{1 /}$ Average values of five temperatures: $9,12,15,18$, and $21^{\circ} \mathrm{C}$ 
presence of thermic stress, the highest sterilities were registered in the inbreds SC491 and SC681 and in the cultivar SCS116 Satoru. The inbred SC676 presented the lowest percentage of spikelet sterility at all five temperatures. All genotypes had larger sterility than the control when exposed to thermic stress. Nonetheless, the smallest numeric difference in the percentage of marked panicle spikelet sterility between stressed plants and control was registered for the inbred SC676.

Across all five genotypes, there was a quadratic decrease in the percentage of tagged panicle spikelet sterility when temperatures increased from 9 to $20{ }^{\circ} \mathrm{C}$, demonstrating that the smallest sterility percentages were obtained at the higher temperatures assessed in the experiment (Figure 2). This behavior reinforced the observations made by Khan et al. (1986), Kaw (1991), Streck et al. (2006), Baruah et al. (2009), Wang et al. (2009), Peyman \& Hashem (2010), and Shinada et al. (2013), emphasizing that extremely low temperatures increase rice spikelet sterility and temperatures above $20{ }^{\circ} \mathrm{C}$ do not compromise grain pollen formation at microsporogenesis. Considering cold-tolerant genotypes, the critical temperatures to trigger spikelet sterility ranged from 15 to $17^{\circ} \mathrm{C}$, whereas for cold-sensitive genotypes, it was between 17 and $19^{\circ} \mathrm{C}$ (SOSBAI, 2014). This information was confirmed in the present study where the greatest sterility rates were detected when plants were submitted to 9,12 , and $15{ }^{\circ} \mathrm{C}$ during microsporogenesis (Table 2 and Figures 1 and 2). On the other hand, when temperatures varied from 18 to $21^{\circ} \mathrm{C}$, plant behavior was similar to that in the control.

Higher sterility rates caused by the exposition to low temperatures have also been reported by Soltani et al. (2001), Farrell et al. (2006), Martins et al. (2007), Jagadish et al. (2008), Weerakoon et al. (2008), Walter et al. (2010), Wang et al. (2013), and Oort et al. (2014). These studies showed that the stress duration is an important factor as a temperature of $12{ }^{\circ} \mathrm{C}$ may not induce sterility if it occurs over a period shorter than $48 \mathrm{~h}$, but can cause $100 \%$ of sterility when plants are exposed for more than six days to this stress, depending on the genotype sensitivity.

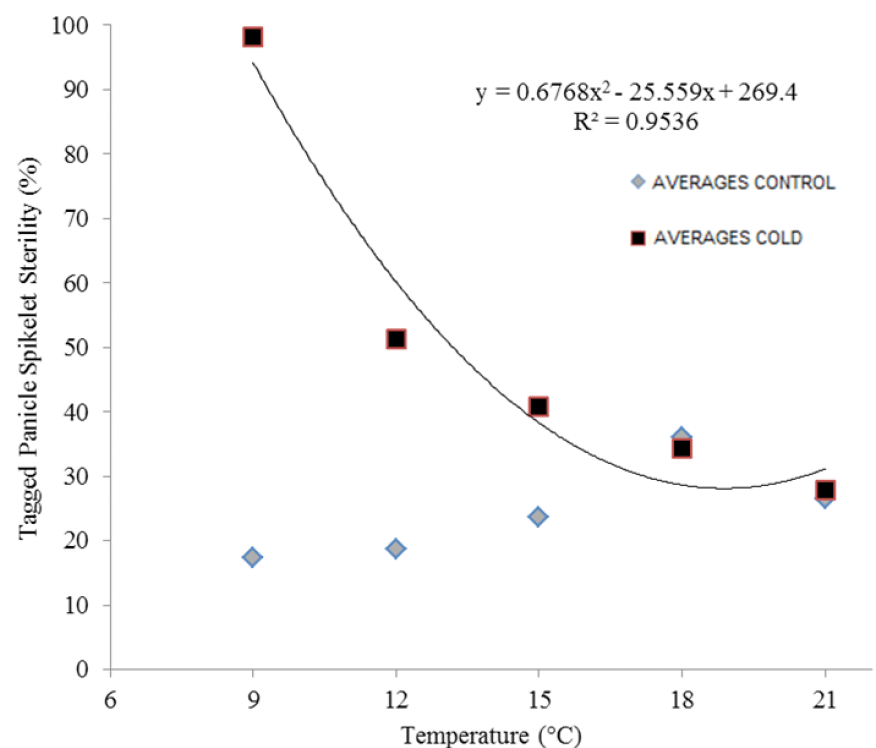

Figure 2. Effect of temperature on the percentage of tagged panicle spikelet sterility, averaged across the five paddy rice genotypes
One of the main objectives of this work was to identify genotypes with high tolerance to low temperatures, allowing cultivation in regions prone to cold periods during rice microsporogenesis. The spikelet sterility data collected in the experiment demonstrated that the inbred SC676 was more suitable than the other genotypes in terms of tolerating low temperatures at rice booting. It was the only inbred for which bulks did not present $100 \%$ sterility when submitted to $9{ }^{\circ} \mathrm{C}$ (Table 2). Furthermore, this genotype presented the lowest increment in percentage of spikelet sterility with temperature reduction (Figure 1). Moreover, it also had the lowest rate of tagged panicle sterility under thermic stress, averaged across the five temperatures (Table 3).

Such characteristics indicate that the inbred SC676 is promising to generate a future rice cultivar with favorable agronomic performance in regions with high risks of low temperatures at microsporogenesis. This behavior corroborates the observations made by Marschalek et al. (2013) in field evaluations performed with this inbred at the High Valley of Itajai.

\section{Conclusions}

1. Temperatures of 9 and $12^{\circ} \mathrm{C}$ at microsporogenesis promote high percentage of paddy rice spikelet sterility, regardless of the genotype.

2. Temperatures of 18 and $21^{\circ} \mathrm{C}$ do not cause significant damage to paddy rice spikelet sterility.

3. The inbred SC676 presents greater tolerance to low temperatures than the other genotypes, therefore being suitable for the generation of a cultivar with adequate agronomic performance in rice production regions prone to cold stress in the South of Brazil.

\section{ACKnOWledgments}

We thank the staff of the Epagri, Itajaí Experimental Station, for providing the structure to carry out the experiments. We also thank the UDESC for granting a study scholarship to the first author and CNPq for providing a research scholarship for the second author.

\section{Literature Cited}

Artacho, P.; Meza, F.; Alcalde, J. A. Evaluation of the ORYZA2000 rice growth model under nitrogen-limited conditions in an irrigated Mediterranean environment. Chilean Journal of Agricultural Research, v.71, p.23-33, 2011. https://doi.org/10.4067/S071858392011000100003

Baruah, A. R.; Ishigo-Oka, N.; Adachi, M.; Oguma, Y.; Tokizono, Y.; Onishi, K.; Sano, Y. Cold tolerance at the early growth stage in wild and cultivated rice. Euphytica, v.165, p.459-470, 2009. https://doi. org/10.1007/s10681-008-9753-y

Counce, P. A.; Keisling, T. C.; Mitchell, A. J. A uniform, objective and adaptive system for expressing rice development. Crop Science, v.40, p.436-443, 2000. https://doi.org/10.2135/cropsci2000.402436x

Cruz, R. P. da; Duarte, I. T. de L.; Cabreira, C. Inheritance of rice cold tolerance at the seedling stage. Scientia Agricola, v.67, p.669-674, 2010. https://doi.org/10.1590/S0103-90162010000600008

Cruz, R. P. da; Milach, S. C. K. Genetic breeding for cold tolerance in paddy rice. Ciência Rural, v.30, p.909-917, 2000. 
Cruz, R. P. da; Milach, S. C. K.; Federizzi, L. C. Rice cold tolerance at the reproductive stage in a controlled environment. Scientia Agricola, v.63, p.255-261, 2006. https://doi.org/10.1590/S010390162006000300007

Farrell, T. C.; Fox, K. M.; Williams, R. L.; Fukai, S. Genotypic variation for cold tolerance during reproductive development in rice: Screening with cold air and cold water. Field Crops Research, v.98, p.178-194, 2006.

Jagadish, S. V. K.; Craufurd, P. Q.; Wheeler, T. R. Phenotyping parents of mapping populations of rice for heat tolerance during anthesis. Crop Science, v.48, p.1140-1146, 2008. https://doi.org/10.2135/ cropsci2007.10.0559

Kaw, R. N. Genetic parameters of cold tolerance in rice. The Indian Journal of Genetics and Plant Breeding, v.51, p.59-65, 1991.

Khan, D. R.; Mackill, D. J.; Vergara, B. S. Selection for tolerance to low temperature-induced spikelet sterility at anthesis in rice. Crop Science, v.26, p.694-698, 1986. https://doi.org/10.2135/ cropsci1986.0011183X002600040011x

Marschalek, R.; Schiocchet, M. A.; Knoblauch, R.; Stuker, H.; Eberhardt, D. S.; Rozzetto, D. S.; Porto, G.; Santos, S. B. dos. Selection of paddy rice genotypes adapted to high land regions prone to low temperatures. In: Congresso Brasileiro de Arroz Irrigado, 8, 2013, Santa Maria. Anais... Santa Maria: Pallotti, 2013. p.181-184.

Martins, A. F.; Vieira, E. A.; Kopp, M. M.; Luz, V. K. da; Carvalho, M. F. de; Castelo Branco, J. S.; Cruz, R. P. da; Carvalho, F. I. F. de; Oliveira, A. C. de. Characterization of rice families to cold tolerance in the vegetative and reproductive phases. Bragantia, v.66, p.227-233, 2007. https://doi.org/10.1590/S0006-87052007000200006

Ñanculao, G. D.; Cárcamo, M. P.; Santos, O. A. de los; Velásquez, V. B. Cold tolerance evaluation in chilean rice genotypes at the germination stage. Chilean Journal of Agricultural Research, v.73, p.3-8, 2013. https://doi.org/10.4067/S0718-58392013000100001

Oort, P. A. J. van; Saito, K.; Zwart, S. J.; Shrestha, S. A simple model for simulating heat induced sterility in rice as a function of flowering time and transpirational cooling. Fields Crops Research, v.156, p.303-312, 2014. https://doi.org/10.1016/j.fcr.2013.11.007

Peyman, S.; Hashem, A. Evaluation of eighteen rice genotypes in cold tolerance at germination stage. World Applied Sciences Journal, v.11, p.1476-1480, 2010.

Rozzetto, D. S.; Marschalek, R.; Stuker, H.; Eberhardt, D. S.; Raimondi, J. V.; Santos, S. B. dos; Porto, G.; Pazini, B. S.; Souza, N. M. de. Cold tolerance of paddy rice genotypes exposed to low temperatures in growth chamber during the reproductive stage. In: Congresso Brasileiro de Arroz Irrigado, 8, 2013, Anais... Santa Maria: Pallotti, 2013. p.185-188.
Shimono, H.; Okada, M.; Kanda, E.; Arakawa, I. Low temperatureinduced sterility in rice: Evidence for the effects of temperature before panicle initiation. Field Crops Research, v.101, p.221-231, 2007. https://doi.org/10.1016/j.fcr.2006.11.010

Shinada, H.; Iwata, N.; Sato, T.; Fujino, K. Genetical and morphological characterization of cold tolerance at fertilization stage in rice. Breeding Science, v.63, p.197-204, 2013. https://doi.org/10.1270/ jsbbs.63.197

Silva, F. de A. S. e; Azevedo, C. A. V. de. The Assistat Software Version 7.7 and its use in the analysis of experimental data. African Journal of Agricultural Research, v.11, p.3733-3740, 2016. https://doi. org/10.5897/AJAR2016.11522

Soltani, A.; Zeinali, E.; Galeshi, S.; Niari, N. Simulating GFDL predicted climate change impacts on rice cropping in Iran. Journal of Agricultural Science and Technology, v.3, p.81-90, 2001.

SOSBAI - Socidade Sul-Brasileira de Arroz Irrigado. Paddy rice: Research technical recommendations for the South of Brazil. Bento Gonçalves: SOSBAI, 2014. 192p.

Streck, N. A.; Bosco, L. C.; Michelon, S.; Rosa, H. T.; Walter, L. C.; Paula, G. M. de; Camera, C.; Lago, I.; Marcolin, E. Evaluation of photoperiodical answer of paddy rice genotypes. Bragantia, v.65, p.533-541, 2006. https://doi.org/10.1590/S000687052006000400001

Tedesco, M. J.; Gianello, C.; Bissani, C. A.; Bohnen, H.; Volkweiss, S. J. Analysis of soil, plants and other materials. 2.ed. Porto Alegre: Universidade Federal do Rio Grande do Sul, 1995. 147p.

Walter, L. C.; Rosa, H. T.; Streck, N.A. Simulação do rendimento de grãos de arroz irrigado em cenários de mudanças climáticas. Pesquisa Agropecuária Brasileira, v.45, p.1237-1245, 2010. https:// doi.org/10.1590/S0100-204X2010001100002

Wang, J.; Lin, X.; Sun, Q.; Jena, K. K. Evaluation of cold tolerance for Japonica Rice varieties from different country. Advance Journal of Food Science and Technology, v.5, p.54-56, 2013.

Wang, Z. F.; Wang, J. F.; Wang, F. H.; Bao, Y. M.; Wu, Y. Y.; Zhang, H. S. Genetic control of germination ability under cold stress in rice. Rice Science, v.16, p.173-180. 2009. https://doi.org/10.1016/ S1672-6308(08)60076-1

Weerakoon, W. M. W.; Maruyama, A.; Ohba, K. Impact of humidity on temperature-induced grain sterility in rice (Oryza sativa $\mathrm{L}$ ). Journal of Agronomy and Crop Science, v.194, p.135-140, 2008. https://doi.org/10.1111/j.1439-037X.2008.00293.x

Zaffari, G. R.; Scheuermann, K. K.; Marschalek, R.; Medeiros, D. S.; Andrade, A. de. Protocol to produce double haploid plants of rice genotypes from the sub-specie Indica by the anther culture. Plant Cell Culture \& Micropropagation, v.10, p.32-40, 2014. 